\section{IJ§ER}

ISSN: 2149-5939
International Journal of Social Sciences and Education Research

Online, http://dergipark.gov.tr/ijsser

Volume: $1(1), 2015$

\title{
The impact of social power bases on perceived trust: Do Turkish managers still follow the Akhi order?
}

\author{
Nurdan Özarallı1
}

\begin{abstract}
Received Date: $01 / 01 / 2017$
Accepted Date: $01 / 02$ / 2017

Abstract

Leadership and power are closely linked issues as leaders rely on certain power bases in order to create managerial influence on subordinates to achieve optimum results. In this study, the concept of managerial power was based on French and Raven's categorization of power bases - reward, expert, referent, legitimate, coercive. One purpose of this study is to explore the power bases used by Turkish managers to influence their employees. Another purpose of this paper is to find out the impact of the power bases on perceived supervisory trust. The paper also discusses whether Turkish managers still act in accordance with an old tradition - akhism. The research questions were examined among a sample of 324 white-collar employees from different companies in the private sector. The results indicate that the power base mostly used by managers is legitimate power; expert power, referent power, coercive power and reward power follow. While personal power (a combination of expert power and referent power) and reward power have positive correlations with supervisory trust, coercive power is negatively correlated with trust in supervisor. Further analyses show that personal power has a positive and coercive power a negative impact on supervisory trust. Finally, the mediating role of personal power bases between position power bases and trust was investigated. Based on the findings, we may conclude that Turkish managers still act in accordance with the principles of Akhism. They resort to legitimate power because they are the masters, which is acceptable by the subordinates considering the high power distance in the Turkish culture. More importantly, they use expert power and referent power to influence their "apprentices". Though past research has addressed relationships between power bases and several work outcomes, the present study contributes to the literature by investigating the two critical elements of superior-subordinate dyadic relationship - power and trust - in a different cultural context. The paper includes implications for which power bases supervisors should develop. As managers' referent power and expert power have significant influences on creating a climate of trust, organizations may provide managers with both formal and informal training that develop skills-based power reflecting qualities associated with expert and referent power.
\end{abstract}

Keywords: Supervisory power bases, Supervisory trust, Culture, Akhism

Jel Classification: M10, M14

\section{Introduction}

Power is defined as the capability to get someone to do something and it involves a relationship between two people (Ivancevich et al., 2011). When people with potential power asymmetries have to work interdependently to meet key organizational goals, social power relationships naturally occur. The notion of interdependence can be seen as a matter of vulnerability as well as a form of power. French and Raven (1959) were the first to propose a theoretical framework that has received considerable attention in studies of social power. In fact, the French and Raven typology takes its roots from the social exchange theory. Within the context of social transactions, power is a governing factor in social exchanges in which the power holder exercises control over the behavior or outcomes of another in a dependent position. In any dyadic relationship, power asymmetries can be expected and the less powerful or the dependent one will

${ }^{1}$ Marmara University, Faculty of Business Administration, Istanbul/Turkey, nozaralli@marmara.edu.tr 
Özarall1, N. (2015). The impact of social power bases on perceived trust: Do Turkish managers still follow the Akhi order?. International Journal of Social Sciences and Education Research, 1 (1), 64-87.

form evaluative perceptions depending on the social power bases employed by the power holder. These perceptions are then likely to lead to important job attitudes such as subordinate satisfaction and organizational commitment (Koslowsky et al., 2001) and subsequent reactions. Managerial power bases can be defined as sources from which a manager takes his or her power to influence followers as a means of achieving group and organizational goals. At this point, we should make a distinction between superficial conformity that a manager receives from subordinates in response to his/her power exercise and on a deeper level the psychological climate he/she creates in subordinates. Little has been done to investigate such deeper psychological processes which are nested in relations between a power holde and the dependent person.

"Trust" is one of those important psychological states that deserves to be considered in any study of interpersonal dynamics. As by definition, trust is a psychological state comprising the intention to accept vulnerability and there is a risk involved, it can be very valuable in social interactions. Trust is a valuable asset for organizations, too. Eliciting employees' feel of trust in an organizational setting is important as it reduces conflict and thus enables collaboration and cooperation (Rousseau et al., 1998). Trust has also been been found to be positively correlated with such organizational outcomes as organizational commitment (Perry, 2004) and organizational citizenship behavior (Van Dyne, et al., 2000). Thus, the present study proposes a theoretical framework that includes social power bases and supervisory trust in the context of social exchange relationships between superiors as "power holders" and subordinates. In an attempt to understand reactions to social power in organizational settings, we will describe how social power bases used by Turkish managers could affect subordinates' trust in their managers in a different cultural context. While doing so, we aim to draw inferences to conclude whether Turkish managers still act in accordance with the "long forgotten" akhi order, a real human-centered management in the old Turkish business culture.

\section{Societal and organizational properties of Turkish culture}

Culture can be defined as "the collective mental programming of the people in an environment" (Hofstede, 1980,16) and refers to the shared values and patterns of behavior among individuals. The national culture values are reflected on the corporate culture and organizational behavior. Especially in so-called strong cultures (vs. loose ones) as the Turkish culture, one can follow that national culture values have significant impact on organizational culture, establishing what is appropriate and important for organizational members. Aycan (2001) defines Turkish culture as a mixture of "Eastern" and "Western" values. Turkish social composition displays a collectivist structure, also measuring high on power distance and high uncertainty avoiding (Hofstede, 1980). Although recent research shows that Turkey has become less hierarchical (Aycan et al., 2000), less uncertainty avoiding (Kabasakal \& Bodur, 1998) and moderately collectivistic, collectivism is still the most dominant organizational value in Turkey (Fikret-Pasa et al., 2001). Collectivism (vs. individualism) is characterized by a tight social framework in which group goals and concerns are valued more than individual goals, needs and rights. In the GLOBE study, in-group collectivism and high power distance was found to be the two predominant characteristics of Turkish culture (Kabasakal \& Bodur, 1998). In-group collectivism is characterized by"the degree to which individuals express pride, loyalty and cohesiveness in their organizations or families" (House et al., 2004, 30). In high power distance cultures, the "less powerful" members of an organization expect and accept the "so-called" unequal distribution of power as opposed to a low power distance context where power use is considered legitimate only when 
Özarallı, N. (2015). The impact of social power bases on perceived trust: Do Turkish managers still follow the Akhi order?. International Journal of Social Sciences and Education Research, 1 (1), 64-87.

the situation calls for it (Hofstede, 1991). Cultural characteristics of Turkish people, rooted in their religion, history and family structure, are manifested in certain management practices and organizational behavior. Following a culturist perspective, we can claim that due to high power distance there exists unequal power relationships between superiors and subordinates in Turkish work organizations. Turkish society and organizations "value" inequality among members with respect to power, status and authority. Fikret-Pasa (1999) investigated the influence behaviors of Turkish leaders and concluded that typical to Turkish organizations, in superior-subordinate relationships the superior assumes ultimate power and authority and the subordinate accepts this "granted authority" and directives without question. High power distance is also related to the dimension of closeness/distance in social relationships. Spencer-Oatey (1997) argues that Asian cultures are likely to attach attributes such as benevelonce, support and kindness to power. Hence, power is not as negatively viewed as in western cultures.

Turkey scores high in femininity implying that rather than focusing on competition, material success, ambition, and limited emotional contact with others, Turkish culture values modesty, caring, quality of life and social relationships. This also reflects in leadership practices of Turkish managers. Sargut (2001) states that for Turkish managers, it is important that subordinates have positive feelings toward them. Thus, they try to maintain good relationships with their subordinates andavoid confrontational and conflicting situations. For Turkish emploees, the ideal leader shows relationship-oriented behaviors (Kabasakal \& Bodur, 998).

Keeping the distance and yet being relationship-oriented implies an implicit benevolent (considerate) paternalistic leadership. Paternalism is a prevalent leadership style in non-Western business organizations. Turkey also carries highly paternalistic values (Aycan \& Kanungo, 1998). Paternalistic leaders combine benevolence with authority. This type of leadership is quite similar to autocratic leadership, except that in paternalism, the leader takes care of the followers like a father would. As to the paternalistic exchange between the leader and the followers, the leader expresses benevolence through his supportiveness, makes decisions in best interests of subordinates with regard to their organizational and even personal problems, and in a way creates a family-like atmosphere in the organization. In exchange for such concern, unquestioned obedience, loyalty, deep respect, commitment and trust is expected on the part of the followers.

The qualities of such superior-subordinate relationship reminds us of the Akhi (Ahi) order which was born out of the Turkish culture and Islamic faith in the 7th and 8th century and stood around until the 19th century (Karagül, 2012). The Akhi order could be described, at the time when it was practiced, an artisan union which had its foundations on generosity, expertise, mutual respect, and trustworthiness. "Akhi" is derived from the Turkish word "Ak1" which means "generous and charitable" as explained in the dictionary of Divan-i Lugat-it Turk - the first dictionary of Turkish language. Akhiis also means "brother" in Arabic language (Akca, 2004, 356). Akhis accept others as brothers. Masters (experts) teach all the details of an occupation or craft to the Akhis, the young apprentices so that the occupation is passed on to other generations. The Akhism as a civil institution would devote the Akhis to learning from their masters all the details of their profession or craft to perfection. The Akhis would respect their Masters, model them and be happy for grasping a craftsmanship (Karatop et al., 2011). The Master, on the other hand, would be responsible for the apprentice Akhis' well-being and their total education regarding their profession/craft. The Master would provide a fatherly compassion and work patiently on his apprentice until he becomes knowledgeable and a well-qualified craftsman. In other words, he is generous 
Özarall1, N. (2015). The impact of social power bases on perceived trust: Do Turkish managers still follow the

Akhi order?. International Journal of Social Sciences and Education Research, 1 (1), 64-87.

and ready to share his assets with his brothers (Çağatay, 1989). The Masters in the Akhi order may well be considered as 'coaches' and 'mentors' in today's business organizations. The master craftsman is both a coach (passing on skills) and a mentor (providing personal development).

Although the morals and principles of Akhism might not have kept pace with the development of modern age, it functioned successfully for about 630 years and the "brotherhood culture" prevalent in Akhism can be expected to be influential in today's social and organizational life. As a long-established notion in its cultural heritage, Turkish organizations might still carry the traces of Akhism as a strong corporate structure, based on master-apprentice relationship. In this relationship, are managers still acting like masters providing subordinates with skills and personal development? Which power bases are they using to harvest trust in return from akhi apprentices - today's subordinates?

\section{Social power bases and supervisory trust}

Power and trust - the two distinct patterns of controlling relationships are interrelated in many ways. First, both mechanisms play an important role in determining the quality of interpersonal relationships and co-ordinates social interactions efficiently. Second, specific forms of power and trust are identified and developed at the interpersonal level on which either trust or power becomes a dominating factor in the relationship. However, since both of them is limited in their capacity, most relationships are usually based on a mixture of both power and trust. Third, specific forms of power do occur within the framework of relationships and are most likely to develop trust between individuals. In fact, the relationship betwen power and trust is rather complicated.

\section{Social power bases}

As power can be conducive to very different qualities of relations, it is important to know how power is exercised and which of those power bases are utilized by power holders to influence the "less powerful". When examining bases of power in an organizational setting, the concept of influence must also be considered. In fact, these concepts are closely linked attributes determining the behavior of superiors over subordinates. The bases of power refer to the ways that managers and leaders use to influence their employees. In fact, leadership and influence are a function of power. French and Raven (1959) first defined social influence as a change in the belief, attitude, or behavior of a "target" person, which results from the action of the "influencing" person. Thus, social power can be defined as the potential to obtain such interpersonal influence, the ability of the power holder to bring about such change in the target of influence. However, the exercise of power may or may not be effective in creating the desired influence. Besides, the mutual influence attempts in which two participants may attempt to influence one another make the issues even more complex (Raven, 2008).

Although there are undoubtedly many possible bases of power, we shall here define five- the classical typology based on the power-influence conceptualization advanced by French and Raven (1959). Such categorization has proven to be among the most popular and noteworthy (Rahim et al., 2000; Elias, 2008), as evidenced by its nearly universal inclusion in many theoretical and empirical studies. French \& Raven (1959) categorized the power bases that managers can use to influence employees as position power: legitimate power, coercive power, and reward power, and personal power: expert power and referent power. 
Özarallı, N. (2015). The impact of social power bases on perceived trust: Do Turkish managers still follow the Akhi order?. International Journal of Social Sciences and Education Research, 1 (1), 64-87.

Subsequently, Raven et al. (1998) further explored various bases of power in an attempt to expand French and Raven's categorization to include "informational power" and other power bases. They proposed a more detailed listing along with persuasive arguments and logic and, yet there have been weaknesses and inconsistencies concerning the origin of power and inadequate demarcation. Gaski (1986) has argued that "these alleged power sources appear to be already captured by the French and Raven framework ... and it has held up well in extensive empirical usage over the years". It seems that there does not appear to be a consensus in the more detailed typologies beyond the five stated above. Thus, these five bases of power will constitute the dimensions of supervisory power bases used in this study.

Legitimate power involves norms or values that legitimize the exercise of power to influence or direct others. It refers to the subordinates' belief that a manager has the right to influence and they have an obligation to accept this influence they comply (Gibson et al., 2012). Legitimate power is derived from the formal authority and there is supposed to be little or no question about whether the targets of influence should comply with the request or not.

Coercive power involves negative control of sanctions and the expectation of punishment. It refers to the ability of the manager to create fear or a perceived threat of reprimands, suspension, demotion or undesirable work assignments if the subordinates do not comply with the manager's directives. Managers should use coercive power with caution as it has negative side effects and creates hard feelings toward those who use it (Lunenburg, 2012).

Reward power involves positive control of sanctions. It refers to the ability of the manager to provide subordinates with monetary and nonmonetary compensation for desired outcomes, such as promotions, praise, desirable work assignments,.. etc.. In order for the manager to use reward power effectively, the connection between the behavior and the reward should be clearly and objectively spelled out (Nelson \& Quick, 2012).

Expert power is derived from the superiors' knowledge, expertise, special skills or abilities related to the work being performed. It refers to the ability of the manager to provide subordinates with recognized knowledge or expertise which subordinates lack or need to perform their tasks. In today's hi-tech organizations, expertise is one of the most important power sources of organization members at all levels in the hierarchy (Luthans, 2011).

Referent power involves the concept of identification. It refers to the ability of the manager to influence followers because they like, admire and respect him/her. Referent power develops out of loyalty, friendship, affection, a desire to gain approval and to be like that person. Leaders who have strong interpersonal relationship skills can gain referent power. This power concept can be considered very close to the important leadership quality of 'charisma'. (Robbins, 2002).

Some of these power bases share similarities. Legitimate, reward and coercive power are sanctioned by an organization, thus they may be called position power or organizational power sources. Power holders have the formal authority and control over rewards and punishments. Managers and executives generally hold all these three sources of power. The expert and referent power bases are personal which stem from the individual's personal attributes such as expertise, charisma and interpersonal relationships. Researchers in the past have brought support to two basic dimensions and often classified legitimate, reward, and coercive into "negative" bases and expert power and referent power into the category of "positive" bases (Frost \& Moussavi, 1992). 
Özarall1, N. (2015). The impact of social power bases on perceived trust: Do Turkish managers still follow the

Akhi order?. International Journal of Social Sciences and Education Research, 1 (1), 64-87.

In fact, most powerful leaders possess these five sources of power at once (Lunenburg, 2012). However, a supervisor's various power sources and ways of influencing by which they achieve the desired outcomes depends on how it is exercised as well as how it is perceived by the subordinates. Some authors (e.g. Steensma \& van Milligen, 2003) have suggested that bases of power are related to the use of particular forms of influence tactics. For example, depending on how it is used, position power could lead to the use of "harsh-influence tactics", which include legitimacy of position, reward and coercion. Such tactics are relatively controlling and coercive and constrain the freedom of organizational members to comply with the leader's demands. Harsh power bases are usually perceived by the targets of influence as rather disagreeable and may produce negative employee attitudes and behaviors. "Soft-influence tactics", on the other hand, result from personal power bases which include expert and referent and give more freedom to organizational members to accept the leader's demands. Soft power bases are favored by the targets of influence as they generate more positive individual and organizational outcomes in the long run future interactions (Koslowski et al., 2001; Steensma \& Vesser, 2007; Pierro et al., 2012). However, depending on the situation and their leadership styles, leaders may use both so-called harsh and soft sources of power together in varying combinations.

Several studies conducted in Turkey on supervisory power bases yielded to various categories. For example, Sarıtaş (1991, 13-14) studied the primary school principals' power bases in three groups: legitimate, expert and referent. Erçetin $(1993,60)$ came up with a more detailed listing and proposed six influence tactics utilized by school principals: position, personality, interest, expert, reward and coercive. Aydin (1994, 274-276) mentioned the power of subordinate training, information, support, persuasiveness, participation, reward, coercive and planning. Most of these dimensions seem to tap the French and Raven categorization.

Several studies pointed out to the significant intercorrelations among the five sources of power. Rahim (1989) concluded that expert and referent power bases are correlated. It seems that subordinates tend to admire and respect a supervisor who possesses a high level of expertise and identify with him/her. In other words, the perception of expert power is conducive to the interpersonal attraction of subordinates and positively influences the perception of referent power. A stream of researchers (e.g., Raven, 2008) also suggest that one power base may sometimes undermine the perception of another. For example, a manager who already has referent power might undermine this power base by emphasizing expertise. In the same way, a power holder who is an expert may reduce the respect for expert power in his/her attempt to increase referent power by emphasizing that $\mathrm{s} / \mathrm{he}$ is really similar to the target of influence.

Gaski (1986) points out to the importance of knowing how power bases are related to each other as each power base may affect outcomes not only directly but also indirectly through the mediation on other sources of power. Raven (1992) also called for understanding how certain power bases affect the other remaining power bases, predicting one power base may evolve into another.

In an attempt to address this issue, we aim to have a closer look at the use and classification of supervisory social power in Turkish work environment, and ask the following research question:

Research Q1: What are the interrelationships among position/organizational (legitimate, reward and coercive) and personal (expert and referent) power bases? 
Özarallı, N. (2015). The impact of social power bases on perceived trust: Do Turkish managers still follow the Akhi order?. International Journal of Social Sciences and Education Research, 1 (1), 64-87.

At the dyadic level of analysis, many researchers have also focused on the perceived supervisory power bases and their impact on workplace attitudinal reactions, including job satisfaction, motivation and organizational commitment as well as behaviors such as absenteeism, performance and turnover (Carlson et. al., 2000; Afza, 2005; Lee \& Tui, 2008; Nadaee et al., 2012). Research has yielded somehow inconsistent results, however. For example, as some researchers found a significantly positive relationship between reward power and global job satisfaction (Elangovan \& Xie, 2000; Afza, 2005), some researchers found no significant relationship (Nadaee et al., 2012). Similarly, while Lee \& Low (2012) found no relationship with supervisory satisfaction, Elangovan \& Xie (2000) found a positive relationship between legitimate power and satisfaction with supervision. Thus, the relationship between legitimate power and reward power with satisfaction are rather inconsistent. In one study, Koslowsky et al. (2001) found that organizational commitment is positively related with all supervisory power bases, whereas Pierro et al. (2007) found that affective organizational commitment is positively related only to expert and referent power base of the supervisors.

It seems that different types of supervisory power are related to subordinate responses in different ways. Several writers concluded, however, that coercive power is generally ineffective in producing positive individual and organizational outcomes. Elangovan \& Xie (2000) reported that coercive power of the supervisor was negatively related with subordinate commitment, performance and satisfaction and it was also associated with higher stress. Nadaee et al., (2012) found no correlation between the two, however.

At the dyadic level of analysis, a stream of past research which focused on employee perceptions of the supervisory power and their effects on key employee-related attitudes and behaviors suggests that expert power and referent power is positively related with organizational commitment, job satisfaction, supervisory satisfaction, motivation and performance (Elangovan \& Xie, 2000; Steensma \& Visser, 2007; Koslowsky et al., 2001).

Studies conducted in Turkey on supervisory power bases and their effects on organizational outcomes also yield to mixed results. For example, Y1lmaz \& Altınkurt (2012) found moderate and positive correlations with all power bases (legitimate, expert, reward, coercive, referent) of the school administrators and teachers' job satisfaction. Reward power, when combined with other power bases however, emerged as the only predictor of teachers' job satisfaction. Altınkurt \& Yilmaz (2012) also found moderate positive correlations between the administrators' power sources and private school teachers' organizational citizenship behaviors. Coercive power, when combined with other power bases however, made the only positive contribution to teachers' organizational citizenship behaviors. Bağc1 \& Bursalı (2011) found that there were significant positive relationships between supervisory expert, legitimate and referent power bases and affective commitment. The writers further concluded that while referent and expert power were positively associated with normative commitment, legitimate, reward and coercive power showed negative associations with normative commitment. On the other hand, all power bases were positively associated with continuance commitment.

The multiple effects of the different sources of power exercised by the supervisor suggest that harsh/negative vs. soft/positive influence tactics type of classifications could be oversimplifications and may require serious consideration. Yukl \& Falbe (1991) also argue that these two types of influence tactics are independent and each has distinct but partially overlapping components. He adds that this type of categorization is not well supported empirically in the literature. It seems 
Özarall1, N. (2015). The impact of social power bases on perceived trust: Do Turkish managers still follow the

Akhi order?. International Journal of Social Sciences and Education Research, 1 (1), 64-87.

that each supervisory power base may have direct or in combination effects on the outcomes depending on the context.

The notion that employees' perception of managers' use of power is an important variable in regard to eliciting crucial organisational outcomes has been widely acknowledged in the West. Undoubtedly, researchers in the East have also paid considerable attention to issues surrounding the exercise of power and certain subordinate responses in organizations. However, limited in previous body of research, are inquiries into the deeper level psychological climates created in subordinates by the use of supervisory power bases. In the present study, we will attempt to fill this gap by enhancing our understanding of the direct and mediating effects of power bases used by Turkish managers on subordinates' trust in a different cultural setting.

\section{Supervisory trust}

By definition, trust refers to a psychological state comprising a willingness to accept vulnerability based on positive expectations of another's intentions or actual conduct (Rousseau et al., 1998). It is an underlying psychological condition which plays an important role in influencing a person's intention and behavior (Morrow et al., 2004). Clarke (2002) argues that trust is a prerequisite element of effective human relations.

There has been a growing interest in the vital role of trust inside and outside the organizations (Hardin, 2004). Scholars (Shockley-Zalabak et al., 2000; Chen \& Dhillon, 2003) defined organizational trust as the overall faith and confidence in the qualities and abilities of superiors, subordinates, coworkers and management; and the willingness to depend on them and be vulnerable based on the positive expectations that trustees will act for the benefit of the trustor. The authors add that a climate of trust in an organization is related with employee satisfaction, commitment and overall perceptions of organizational effectiveness and enhances teamwork, knowledge creation, innovation, goal setting, leadership and performance appraisal.

Supervisory trust functions on a more micro level and refers to employees' faith and confidence in their supervisor that he/she will act for the welfare of employees (Podsakoff et al., 2000). The asymmetries of power and status inherent in superior-subordinate relationship make the issues of vulnerability and dependency particularly salient. Besides, supervisors are the key link in any organization between upper management and lower-level employees and their unique role in the subordinates' and organization's success cannot be underestimated. The importance of trust in supervisor/leader has been explored and emphasized for a long time and especially in workplace, employees' trust in their supervisor have been found to be related to many important work attitudes and behaviors. Employees with higher trust in their supervisor are more satisfied with their job and supervisor, have higher commitment to organization, and build better relationships with their supervisor (Dirks \& Ferrin, 2002). Moreover, when employees trust in their supervisor, they also perform better, stay with the organization and are willing to engage more in extra-role behaviors (Wasti et al., 2007; Mayer et al., 2011). Liao (2008) also concluded that manager's use of referent power and expert power are conducive to creating a climate of trust which leads to effective knowledge-sharing in R\&D departments. Blau (1964) emphasized the role of trust in the emergence and maintenance of a social exchange relationship. In other words, social exchange is based on trusting others to reciprocate and elicit work-related attitudes.

In the Turkish society dominated by collectivist and paternalistic values, we can assume that trust serves as a key ingredient for the social integration of individuals and well-being and is built 
Özarallı, N. (2015). The impact of social power bases on perceived trust: Do Turkish managers still follow the Akhi order?. International Journal of Social Sciences and Education Research, 1 (1), 64-87.

into the interpersonal relationships as well as the structure of organizations. Turkish managers are both autocratic and benevolent and assume the role of parents considering it an obligation to provide their subordinates with affection and protection. In turn, they expect from their subordinates loyalty, respect, commitment and trust. In fact, much of the literature implies a strong positive relationship between trust and collectivism (Doney et al., 1998). Although collectivist cultures could inhibit trust formation due to the sharp distinction between in-groups and out-groups, the authors argue that collectivists have a more interdependent world view and thus, nurture interpersonal relationships with care. Based on the significance and potential benefit of trust to organizations, it seems worthy to take a deeper look on how employees' trust form and what factors effect or strengthen them.

\section{Social power bases and supervisory trust}

Studies that have been conducted in different sectors point out to the relationship between social power bases and subordinate attitudes. Gupta \& Sharma (2008), for example, found that social power bases used by supervisors affect subordinates' attitudes towards superiors and the whole organization. Some researchers have focused on the relation between social power bases and trustworthiness as well. Steensma \& Visser (2007) found positive correlations between expert and referent power and supervisory trust. Aguinis et al., (1996) reported that faculty supervisors with low coercive power or with high legitimate power are seen as more trustworthy. Studies on supervisory power bases and trust in the Turkish context is rather limited. One recent study conducted by Bozaykut (2009) in public hospitals in Turkey revealed that except for legitimate power all other power bases have significant contributions to supervisory trust. In her study, perceived coercive power had the highest negative correlation with trust in supervisor. In general, we can predict that the use of coercive power may weaken exchange relationships and reduce trust, while use of non-coercive influence tactics is supposed to strengthen exchange relationships and increases trust.

In an attempt to find out the relationship between supervisory power bases and subordinates' trust, we ask:

Research Q2: How do supervisors' power bases relate to the subordinates' trust in their supervisors/managers?

Although there has been extensive research on social power from a wide variety of perspectives, research on the interrelationships among power bases and their direct as well as mediating effects is rather limited. Rahim et al., (2001), for example, points out to the consensus among numerous studies which show that coercive, reward, and legitimate power bases are weak predictors of job performance. As an alternative explanation to these findings, the authors suggest that expert and referent power bases might act as a mediating variable on the relationship between coercive, reward, and legitimate power bases and job performance. In other words, the perception of the position power base has an impact on the personal power base, which in turn, influences the outcome interpersonal or organizational variables.

These findings sound reasonable as supervisors who use reward power in a fair manner along with the legitimate power base may be perceived by their subordinates as competent and also benevolent. Considering the complex pattern of relationships between supervisory social power bases and subordinate responses, we may argue that perception plays an important mediating role between supervisory power bases and subordinate attitudes or behaviors. 
Özarall, N. (2015). The impact of social power bases on perceived trust: Do Turkish managers still follow the

Akhi order?. International Journal of Social Sciences and Education Research, 1 (1), 64-87.

Such discussions in power bases literature suggest that personal (expert and referent) power bases may mediate the relationship between position power bases (legitimate, coercive, and reward) and certain organizational variables.

In order to explore the direct and mediating effects of supervisory power bases and trust in immediate supervisor, we ask the following research question:

Research Q3: Will supervisors' personal power bases (expert and referent) mediate the relationship between position power bases (legitimate, coercive, and reward) and the subordinates' trust in their supervisors/managers?

\section{Method}

\subsection{Sample and procedure}

A key focus of the present study is the relationship between subordinates' views of supervisory power bases and the trust they feel for their supervisors. Therefore, we gathered data in multiple organizations to increase variance in supervisory power bases. Data were gathered at organizations from a variety of areas including telecommunication, finance, pharmaceutics, IT, production, and retail. Participants were contacted through their employing organization, and the questionnaires were mailed to respondents' e-mail addresses through a web survey. Respondents were requested to send the questionnaires back after completion. Participation was voluntary and all participants were assured that their individual responses would be totally confidential. Through convenience sampling, a total of 500 questionnaires were distributed and 324 completed questionnaires were saved in our database with a response rate of 64 per cent. After deleting records with missing values, 324 questionnanires were found to be usable and constituted the sample for this study.

182 respondents were male and 142 female. On the whole, the education level of the participants was high. $8 \%$ of respondents were high school graduates while $60 \%$ university graduates and $32 \%$ with a post-graduate degree. The high educational level was reflected in the position held by the respondents. As to seniority, $46.6 \%$ of the participants had a managerial position $(\mathrm{N}=150)$, while $53.5 \%$ worked at non-managerial positions $(\mathrm{N}=173) .59 \%$ of the respondents were married. The average age and work experience of the respondents were 36 and 12.8 years, respectively. The mean organizational tenure of the respondents was 6.27 years. Respondents have worked with their present supervisor for an average of 4 years.

\subsection{Instruments}

The present study relied on self-report and subjective perceptions of the participants. The survey contained scales for each of the variables in our study.

Social Power Bases: Hinkin \& Schriesheim's (1989) scales were used to measure the five social power bases- reward power, coercive power, legitimate power, reference power, and expert power. These scales consist of 20 items (four items per power scale). The translation of the questionnaires from English into Turkish was conducted by the researcher following standard procedures used in intercultural research.

Trust in Supervisor: Trust in supervisor was measured using a scale developed by the author. The scale was derived from the literature on supervisory trust (Mayer \& Davis, 1999; McAllister, 1995) and designed to elicit information on employee perceptions of supervisory trust on five 
Özarall1, N. (2015). The impact of social power bases on perceived trust: Do Turkish managers still follow the Akhi order?. International Journal of Social Sciences and Education Research, 1 (1), 64-87.

trust facets: competence, care, justice, benevolence, and integrity (all derived from extensive research with Turkish employees). The scale consists of 11 items and includes such items as "I feel very confident that my supervisor can take sound decisions about work", "My supervisor is very concerned about his/her employees' welfare and their problems", "My supervisor is fair in dealings with his/her subordinates", "I can count on my supervisor for help if I have difficulties with my job", and "I have complete trust that my supervisor will stick to his/her word".

In all scales respondents were asked to indicate the extent of agreement or disagreement with the questions on a six-point scale ranging from (1) strongly disagree to (6) strongly agree.

\section{Results}

The data were analyzed with SPSS 16,0. Factor analyses using a principle components analysis with varimax rotation was applied to the 20 items representing the dimensions of social power bases to determine whether the five factors proposed by French and Raven would emerge again. This analysis will also show whether the harsh $v s$. soft dichotomy of power bases exists in the Turkish context, considering the cultural differences between the United States and Turkish cultures. The analysis extracted four dimensions. Referent power and expert power collapsed into one factor which we named "personal power". These four factors accounted for 78,670 percent of the total variance with Eigenvalues 1 or greater (Table 1).

Table 1. Factor analyses of Social Power Bases Scale

FACTOR 1: Personal Power (\% Var: 41,164) Factor loadings

I feel my manager can share with me his/her considerable experience and training

I feel my manager can provide me with sound job-related advice.

I feel my manager can make me feel important.

I feel my manager can give me good technical suggestions.

I feel my manager can make me feel like he/she approves of me.

I feel my manager can make me feel valued.

I feel my manager can make me feel personally accepted.

I feel my manager can provide me with needed technical knowledge.

FACTOR 2: Coercive Power (\% Var: 22,470)

I feel my manager can make being at work distasteful.

I feel my manager can make my work difficult for me.

I feel my manager can make things unpleasant here.

I feel my manager can give me undesired job assignment.

FACTOR 3: Reward Power (\% Var: 9,771)

I feel my manager can influence my getting a pay raise.

I feel my manager can increase my salary.

I feel my manager can provide me with special benefits.

I feel my manager can influence my getting a promotion.

FACTOR 4: Legitimate Power (\% Var: 5,265)

I feel my manager can give me the feeling I have responsibilities to fulfill.

I feel my manager can make me feel like I should satisfy my job requirement.

I feel my manager can make me recognize that I have tasks to accomplish.

I feel my manager can make me feel that I have commitments to meet.

Total variance explained: 78,930

Kaiser-Meyer-Olkin Measure of Sampling Adequacy: 0.887; df: 190

Bartlett significance value: 0.000; Approx. Chi-Square: 1008.803

Scale's Cronbach alpha: .91 
Özarall, N. (2015). The impact of social power bases on perceived trust: Do Turkish managers still follow the

Akhi order?. International Journal of Social Sciences and Education Research, 1 (1), 64-87.

Although we had predicted the five separate factors of power bases, referent power and expert power emerged as one factor which we reclassified as "personal power" as Yukl (1981) labeled it. Our finding suggests that different types of power exercised by the supervisor may have multiple effects. It seems that the respondents perceived the two power bases as one personal attribute and identified themselves with their supervisor who was also the provider of expertise.

There exists evidence that while coercive, reward, and legitimate power bases can be classified as position power base, expert and referent power bases can well be called as personal power base. Our finding in a different cultural setting is consistent with Yukl \& Falbe's (1991) work. Trust in Supervisor scale yielded to one factor solution.

Table 2 provides the means, standard deviations, Cronbach alpha reliability coefficients and intercorrelations among social power bases and trust in supervisor. In general, the bivariate correlations reflect expected relations and provide confidence that the measures functioned properly for the effects tested in this study.

Table 2. Means, standard deviations, inter-correlations, and alphas for the variables

\begin{tabular}{|l|l|l|l|l|l|l|l|}
\hline Variables & Means & SD & 1 & 2 & 3 & 4 & 5 \\
\hline 1. Legitimate power & 4.44 & 1.01 & $(.90)$ & & & & \\
\hline 2. Coercive power & 3.89 & 1.34 & $.54^{* *}$ & $(.93)$ & & & \\
\hline 3. Reward power & 3.55 & 1.31 & $.29^{* *}$ & $.26^{* *}$ & $(.89)$ & & \\
\hline 4. Personal power & 4.29 & 1.12 & $.35^{* *}$ & .03 & $.55^{* *}$ & $(.95)$ & \\
\hline 5. Trust in supervisor & 4.26 & 1.11 & .08 & $-.28^{* *}$ & $.36^{* *}$ & $.67^{* *}$ & $(.96)$ \\
\hline$* *$ Significant at $\mathrm{p}<0.01,2$-tailed \\
$*$ Significant at $\mathrm{p}<0.05$ level \\
Internal consistency alphas are in parenthesis along the diagonal. \\
\hline
\end{tabular}

Table 2 shows that all Cronbach's alpha reliability coefficients are high enough to conclude that all scales are highly reliable "good" measures. Table 2 also shows the means which are (slightly) above the theoretical midpoint (3.5) of the scales. Legitimate power scores the highest, reward power the lowest. It seems that the Turkish managers in our study rely more on legitimate power and the least on reward power.

The Pearson Correlation results shown in Table 2 provided intercorrelations among the supervisory power bases. As an answer to research Question 1: What are the interrelationships among position (legitimate, coercive and reward) and personal (expert and referent) power bases?, we can see that position power bases (legitimate, reward, and coercive) are significantly correlated with each other. As legitimate power showed medium-to-low correlations with reward and personal power $(\mathrm{r}=.29$ and $\mathrm{r}=.35$ respectively), it was highly correlated with coercive power $(\mathrm{r}=.54)$. It seems that the amount of coercive power perceived to be held by superiors is associated with the legitimate position they hold in their organization. However, the low correlation between legitimate power and reward power suggests that managers rely more on negative or punishing outcomes rather than positive or rewarding ones. These findings seem consistent with the cultural properties of Turkey. As shown in Table 1, expert power and referent power formed one factor which was named "personal power" and this factor correlated the highest $(\mathrm{r}=.55)$ with reward power. Personal power had a relatively lower correlation $(\mathrm{r}=.35)$ with legitimate power. These findings are consistent with Gaski's (1986) work who also reported positive relationships of expert and referent power bases to reward and legitimate power base. Personal power, on the other 
Özarallı, N. (2015). The impact of social power bases on perceived trust: Do Turkish managers still follow the Akhi order?. International Journal of Social Sciences and Education Research, 1 (1), 64-87.

hand, had no correlation with coercive power. Coercive power does not seem to be a suitable power base for gaining acceptance and recognition.

Table 2 and Table 3 provide preliminary answers to Research Q2: How do supervisors' power bases relate to the subordinates' trust in their supervisors/managers?

The supervisory bases of power, except for the legitimate power, showed significant Pearson product-moment correlation relationships with supervisory/managerial trust. The legitimate power had no correlation with trust. It suggests that as subordinates responses reflect the normative acceptance of the position of their superiors, it is by no means related with the trust they feel for their superiors. Reward power, on the other hand, had a low-to-moderate positive correlation with supervisory trust $(\mathrm{r}=.36)$. Personal power (the combination of expert and referent power) correlated the highest $(\mathrm{r}=.67)$ with supervisory trust among other power exercises. Supervisors' coercive base of power is negatively related with the subordinates' trust in their supervisors/managers. There is a low-to-moderate negative correlation with coercive power and supervisory trust $(\mathrm{r}=-.28)$.

To move a step forward in our analyses, a regression analysis is performed to see more closely the joint effects of supervisory power bases on trust in supervisor.

Table 3. Multiple regression analysis predicting the impact of supervisory power bases on supervisory trust

\begin{tabular}{|l|c|c|c|}
\hline \multicolumn{5}{|l|}{} \\
\hline Independent Variables & Beta & $\mathrm{t}$ & Sig \\
\hline Reward power & .111 & 1.591 & n.s. \\
\hline Personal power & .610 & 9.026 & .000 \\
\hline Coercive power & -.310 & -5.311 & .000 \\
\hline $\mathrm{F}=58.264$ & & \\
$\mathrm{R}^{2}=.53$, Adjusted $\mathrm{R}^{2}=.52$ & \\
n.s. $=$ non-significant & & \\
\hline
\end{tabular}

In order to answer Research Q2: How do supervisors' power bases relate to the subordinates' trust in their supervisors/managers?, we conducted a multivariate multiple regression analyses to see the impact of power bases on supervisory trust. As legitimate power did not exhibit a significant Pearson product-moment correlation relationship with supervisory trust, we did not include it in the regression analyses. As shown in Table 3, parameter estimates indicate that personal power and coercive power emerge as good predictors of supervisory trust.

Personal power (expert and referent power) makes a significant positive contribution $(\beta=.61$, $\mathrm{p}=.000$ ) on supervisory trust. This finding suggests that expert and referent power together represent a high level of internalization or inner acceptance by the subordinates. The contribution of coercive power on supervisory trust is significantly negative $(\beta=-.31, p=.000)$. The use of coercive power which is derived from control over punishing outcomes seems to have a negative effect on the leader-subordinate relationship. It seems that employees being "coerced" tend to trust in their supervisor less.

An interesting finding relates to managerial use of reward power. Reward power did exhibit a positive Pearson product-moment correlation with supervisory trust $(\mathrm{r}=.36)$; however, it lost its contribution on supervisory trust when combined with other power bases. The results suggest that 
Özarall1, N. (2015). The impact of social power bases on perceived trust: Do Turkish managers still follow the

Akhi order?. International Journal of Social Sciences and Education Research, 1 (1), 64-87.

the role of reward power on supervisory trust deserves further study. Although reward power is categorized as a non-coercive or soft power base, it stems partly from legitimate power and authority to reward others and can be regarded as one form of positional power. As this form of power base suggests the supervisors' control over rewards and subordinates' dependence on their supervisors to get the rewards they strongly desire, the exercise of this power base is a sensitive issue and it may show less inner acceptance by the subordinates.

In order to answer Research Q3: Will supervisors' personal power base (expert and referent) mediate the relationship between position power bases (legitimate, coercive and reward) and the subordinates' trust in their supervisors/managers?, mediation analysis was conducted. Three regression equations as suggested by Barron \& Kenny (1986) were used to test the role of personal power base as a mediator between each position power base (legitimate, coercive, and reward, respectively) and supervisory trust. Two mediation analyses revealed that personal power base did not mediate the relationship between legitimate power or coercive power and supervisory trust. In order to test whether personal power base acts as a mediator between reward power and supervisory trust, first supervisory power was regressed on reward power $(\beta=.36, \mathrm{p}<.001)$. Secondly, personal power was regressed on reward power $(\beta=.55, \mathrm{p}<.001)$. Finally, supervisory power was regressed on both reward power $(\beta=.04)$ and personal power $(\beta=.67, \mathrm{p}<.001)$.

Table 4. Multiple regression analysis testing the mediator effect of personal power

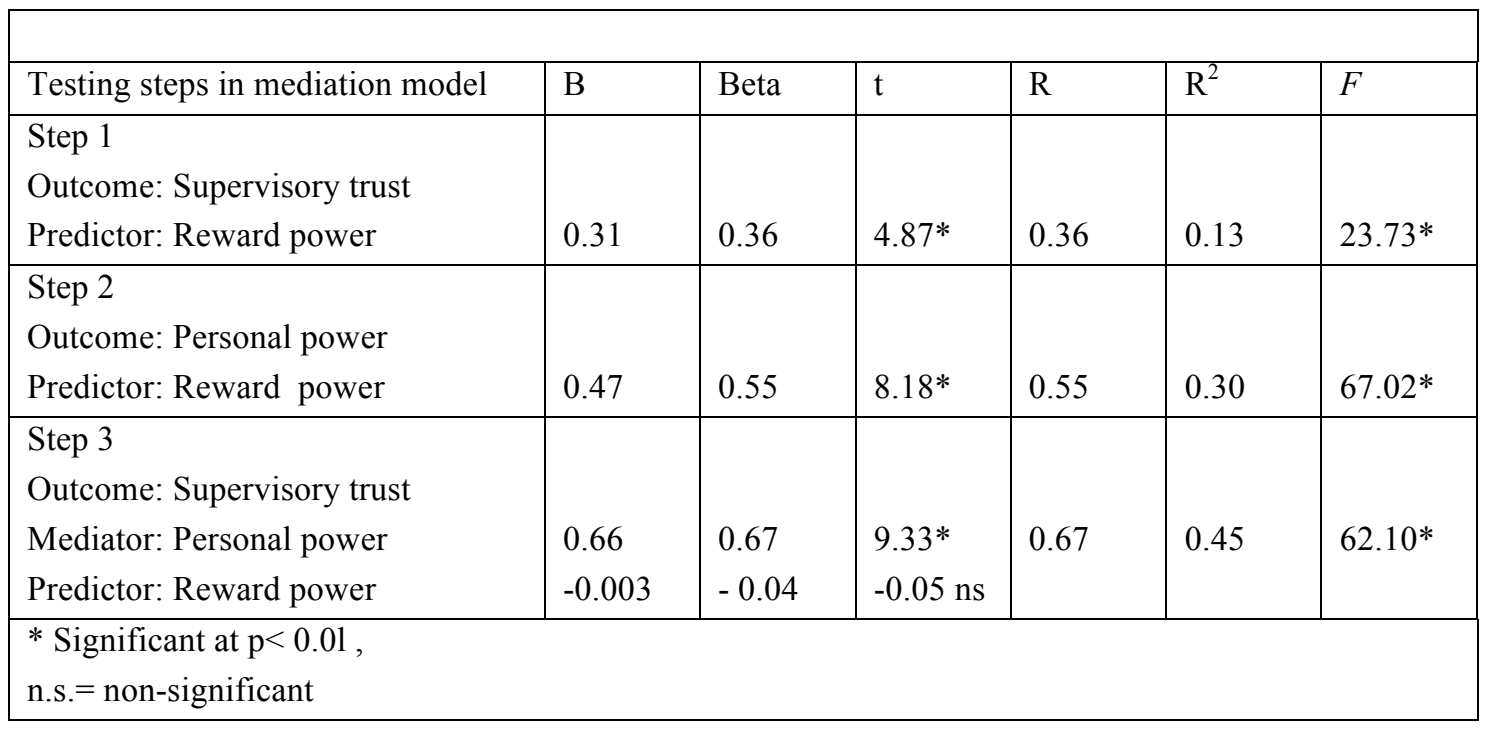

The results of the mediator analyses shown in Table 4 indicate that the personal power base variable significantly mediates the relationship between reward power and supervisory trust. This finding suggests that reward power as a position power base influences the personal power base, which in turn, influences supervisory trust.

Based on the results obtained in this study, we can propose a model (Figure 1) depicting our three research questions. Overall, the model suggests that legitimate power base is not correlated with supervisory trust and coercive power is negatively associated with supervisory trust. Reward power, on the other hand, positively influenced personal power, which in turn, positively influenced supervisory trust. 
Özarallı, N. (2015). The impact of social power bases on perceived trust: Do Turkish managers still follow the Akhi order?. International Journal of Social Sciences and Education Research, 1 (1), 64-87.

Figure 1. Direct and Mediation effects of power bases on trust in supervisor

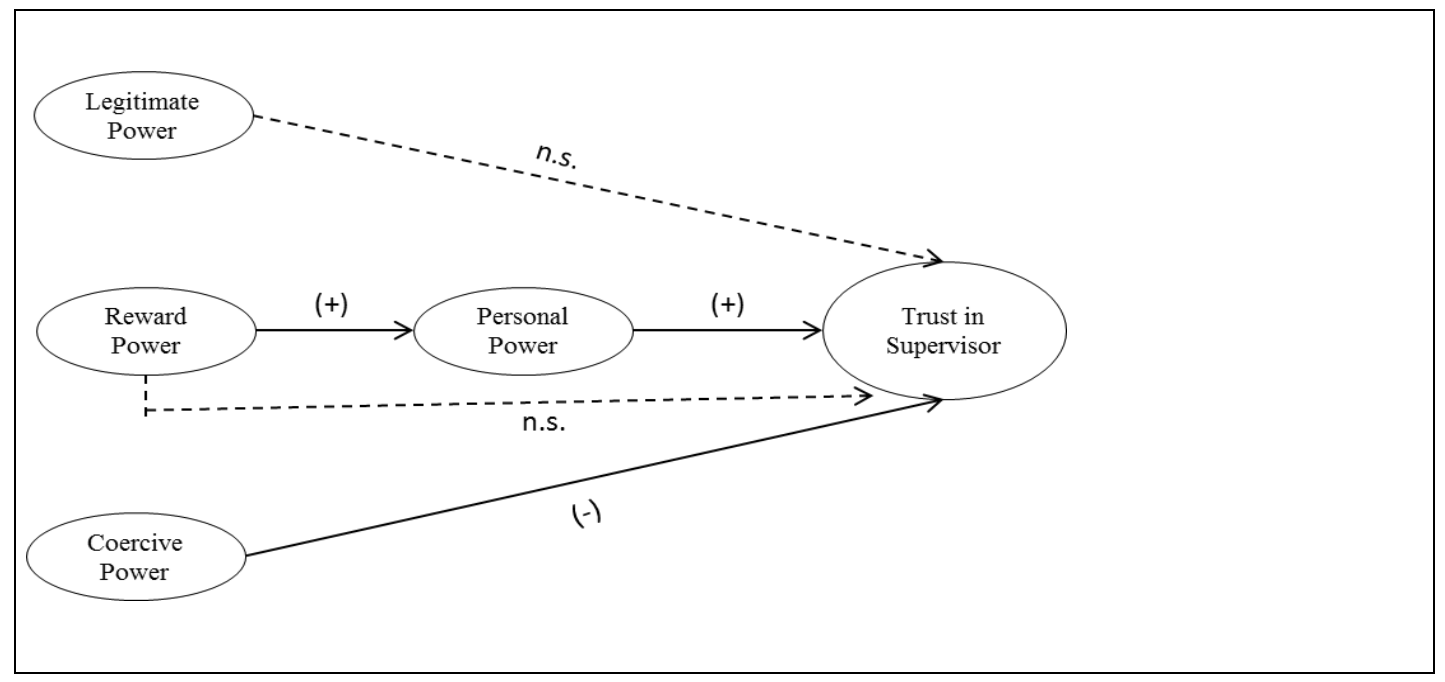

\section{Discussion}

This study examined the individual and combined effects of supervisory power bases on supervisory trust within a collectivist culture. In general, the results of the study were quite consistent with previous organizational studies on supervisory power bases. Intercorrelations among the five power bases showed that French \& Raven (1959) power bases are not mutually exclusive (Table 1 and Table 2). Expert and referent power bases collapsed into one factor, which we named "personal power". Personal power base was the most closely related with reward power followed by legitimate power. Personal power was not related with coercive power. The findings suggest that the Turkish sample in our study attach professional expertise to such attributes as benevelonce, support and kindness and perceive it as one personal power base. Considering the cultural qualities of Turkey, this finding is consistent with the employees' expectations from a paternalistic leader who is the provider of both expert knowledge and benevolence. The high correlation of the personal power with the reward power (one of the position power bases) suggests that the more supervisors' are perceived as reward providers, the more personal power is attached to them by their subordinates. The low-to-moderate relationship of personal power with legitimate power is also an expected finding as far as high power distance within the Turkish culture is considered. In fact, the use of the legitimate power which is tied to the Weberian concept of "legitimate authority" scored the highest among all the other supervisory power bases. The use of personal, coercive and reward power follow, respectively. The use of legitimate and personal power implies the "benevolent authoritative" quality of paternalistic management. It is an interesting finding that the managers rely the least on reward power to influence their subordinates. The results of Y1lmaz \& Altınkurt's (2012) and Aslanargun's (2009) studies conducted in primary and high schools in Turkey also showed that legitimate power is used the most and reward power the least by the school principals. It seems that Turkish managers resort more to legitimate, personal and coercive power bases compared to reward power. This finding can also be attributed to the properties of Turkish culture.

This study also examined the relationships between perceived supervisory power bases and supervisory trust. The results showed that personal power which combined both expert and refer- 
Özarall1, N. (2015). The impact of social power bases on perceived trust: Do Turkish managers still follow the Akhi order?. International Journal of Social Sciences and Education Research, 1 (1), 64-87.

ent power was a major predictor of supervisory trust. Employees tend to trust their supervisors/managers more as they receive expert knowledge and assistance combined with feelings of admiration and identification. It seems that personal power bases represent a high level of internalization or inner acceptance and thus has a positive effect on the leader-subordinate relationship.

Reward power was also positively related to supervisory trust. This finding suggests that subordinates tend to trust their superiors who provide merit recognition for good performance. In fact, researchers in the past (e.g. Frost \& Moussavi, 1992) have often classified reward power into "negative" bases along with legitimate and coercive power as it is based upon an individual's position and authority in an organization. The promise of reward or the fear of punishment may gain a manager complience but this implies subordination rather than voluntary acceptance on the part of the subordinates. In fact, past research results on reward power tend to be mixed implying there is no clear and consistent trend with respect to its effectiveness. Frost \& Moussavi, for example, found a negative relationship between reward power and supervisory trust. In a sense, reward power is closely related to coercive power and thus may show less inner acceptance. However, we may assume that the proper use of reward power is likely to increase the attraction between the superior and subordinate as this study may suggest.

Legitimate power perceived to be held by a supervisor was not associated with supervisory trust at all. As the highest mean score of legitimate power would suggest the normative acceptance of the supervisory position, this power base is by no means related with supervisory trust. This finding is consistent with Yukl (1981) who claims that out of non-coercive power bases legitimate power is a less effective means of influence attempt. However, our study was conducted in private sector with highly educated white collar employees. Depending on the context of the work environment, for example in the public sector or with blue collar employees we may come up with different results.

Negative relationship between coercive power and supervisory trust implies that supervisors who exercise coercion and negative control on sanctions are not likely to receive trust from their subordinates. Similar findings were found by Hinkin \& Schriesheim (1989) and Rahim (1989) which supported the notion that coercive power may lead to short-term compliance, but in the long-run produces negative job attitudes and dysfunctional behavior.

Our findings support past research that revealed effective leaders do rely most on expert and referent power to extract positive employee attitudes, whereas the use of legitimate and coercive power tend to be negatively correlated, or uncorrelated, with leadership effectiveness. In a similar study conducted by Mayer et al. (2011) supervisory use of expert, referent, and reward power were found to be effective in building supervisory trust while the use of legitimate and coercive power was not helpful in the development of trust at all.

It seems that different types of supervisory power are related to subordinate responses in different ways. An analysis which was run to see the relationship between the four power bases all combined and supervisory trust indicated that personal power makes the most positive and coercive power makes a negative contribution on supervisory trust (Table 3). Combining all supervisory power bases in one multiple regression analysis resulted, however, in nonsignificant regression weights for legitimate power and reward power. Legitimate power is by no means related with supervisory trust. Reward power might be an important predictor of supervisory trust in real life; however, it seems to lose its contribution on supervisory trust when combined with other power bases as perceived by subordinates. Our findings suggest that in carrying out their mission, 
Özarallı, N. (2015). The impact of social power bases on perceived trust: Do Turkish managers still follow the Akhi order?. International Journal of Social Sciences and Education Research, 1 (1), 64-87.

those in leadership or managerial roles in healthy organizational cultures should use humanistic and educational as well as non-threatening and non-coercive approaches to create an organizational culture based on trust rather than fear, anxiety and distrust.

The results of the mediator analyses (Table 4) indicate that as personal power base did not mediate the relationship between legitimate power or coercive power and supervisory trust, it does act as a mediator between reward power and supervisory trust. In other words, the once significant contribution of reward power drops to insignificance and this finding suggests that reward power may be related to supervisory trust through another variable-namely personal power. With the inclusion of personal power in the analysis, the effect of reward power on supervisory trust dropped with respect to the case while personal power was not in the analysis. Our finding gives support to Rahim et al., (2001) who stated that subordinates' perception of coercive, reward, and legitimate power bases only weakly predicts job performance. He drew attention to an alternative explanation in that personal power bases may mediate the relationship between position power bases and job performance. Similarly, our study suggests that subordinates' perception of reward power base is a weak predictor of supervisory trust. Superiors should be cautioned about the sensitive nature of reward power. Managers who use a performance-contingent reward power base may be perceived by their subordinates as competent and benevolent. This perception, in turn, seems to contribute to supervisory trust. Considering the characteristics of Turkish culture with high power distance and highly paternalistic values, the results make sense.

Overall, this study contributed to our understanding of supervisory power bases and how they relate to supervisory trust in a different cultural context.

Based on the findings of the present study, we may conclude that Turkish managers still act in accordance with the principles of Akhism. They resort to legitimate power because they are the masters, which is acceptable by the subordinates considering the high power distance in the Turkish culture. More importantly, they use expert power and referent power to influence their "apprentices". They provide them with skills and expertise along with care and affection-in turn of which they receive trust. In a way, our study confirms that Akhi and paternalistic values are still there influencing organizational members.

As Knapp $(1990,17)$ also argues managers who are high on expert power with high cognitive abilities and who are also high on referent power "make meaning for others and give them a sense of purpose. They are able to generate trust, openness and respect by using these same qualities in their interactions with others".

\section{Conclusion}

The main focus of this research paper was to develop a representational "power bases model" of management practice as used today by Turkish managers. It was also aimed to find out whether these power bases are any similar to those in the Akhi tradition. Overall, the results of the study highlight the importance of "relationship" still as a key factor in the Turkish work environment. It seems that regardless of the other power bases that are operating at the same time (such as legitimate, reward, or coercive), Turkish managers resort more to expert and referent power in order to create a dyadic trust climate. Thus, we can claim that within Turkish work environment, power sources based upon personal attributes rather than the ones based upon an individual's position and authority seem to be more crucial in eliciting positive employee attitudes and should be emphasized by the managers the most. 
Özarall1, N. (2015). The impact of social power bases on perceived trust: Do Turkish managers still follow the

Akhi order?. International Journal of Social Sciences and Education Research, 1 (1), 64-87.

The current research contributes to theory in the area of supervisory power and trust by suggesting a model which links power bases to supervisory trust in a collectivist culture. From a practical perspective, the results provided some tentative, but hopefully useful guidance to managers as to how to influence subordinates in order to build trust - an important psychological state. However, as with leadership styles each power base has its place in management and can be used effectively depending on how and how much it is exercised in different contexts and different circumstances.

In fact, the close interelationship between the concept of power and leadership has been recognized over many years. Leadership is, by definition, the ability of a person to influence others towards achieving organisational goals (Robbins, 2003, 314). In other words, as DuBrin (2004, 178) comments, "To exercise influence, a leader must have power".

Based on the results of our study, we can claim that the "personal" power base which emerged as the combination of expert and referent power is very much related with transformational leadership. Transformational leadership is all about providing knowledge, inspiration, charisma and consideration for others (Bass \& Avolio, 1990) - those supportive and benevolent qualities which are also included in the personal power base. In the same way as expert and referent power bases are correlated positively with supervisory trust, the transformational leadership is also strongly predictive of trust (MacKenzie et al., 2001; Dirks \& Ferrin, 2002; Gillespie \& Mann, 2004). Some researchers (e.g. Jung \& Avolio, 1999) propose that transformational leadership is more valued and associated with leadership success in collectivist cultures. They are convinced that subordinates from collectivist cultures work more effectively with transformational leaders who provide care, knowledge, support, consideration and charisma. On the other hand, the other three power bases - legitimate, reward and coercive - seem very much related with transactional leadership. Transactional leadership is all about providing contingent rewards that satisfy employee needs (Gillespie \& Mann, 2004) and management-by-exception as punishment or negative feedback in case subordinaes fail to perform properly. Jung et al. (1995) also commented that high uncertainty avoidance and high power distance cultures (such as Turkey) may require more transaction-based leadership. However, transactional leader behaviors can engender trust in leadership only if subordinates perceive justice, predictability, recognition and reward contingencies which are indicators for leader benevolence and caring within that exchange relationship (MacKenzie, Podsakoff \& Rich, 2001; Dirks \& Ferrin, 2002; Gillespie \& Mann, 2004). It entails that transformational leader behaviors play a mediating role between transactional leadership and trust. Thus, we may consider, though tentatively, the direct and indirect relationships of power bases to supervisory trust (as summarized in Figure 1) as the relationships of transformational and transactional leadership styles to supervisory trust. It seems that studying bases of power should start with closely examining leader behaviors. Although French \& Raven's (1959) power typology has been universally the most frequently used and cited categorization, in future attempts to develop a comprehensive measure of power bases utilized by Turkish managers, it might be a good idea to study the leadership behaviors specific to this culture.

In general, the results of the study are quite consistent with previous supervisory power studies conducted in the West. Turkish collectivist culture does engender those five primary sources of power initially identified by Western researchers, which may bring us to make a claim about the universality of such classifications. Actually, "power" is a universally applicable concept. How- 
Özarallı, N. (2015). The impact of social power bases on perceived trust: Do Turkish managers still follow the Akhi order?. International Journal of Social Sciences and Education Research, 1 (1), 64-87.

ever, differing combinations of supervisory power bases may vary in their ability to predict different subordinate criteria variables in different cultural contexts. The research questions tested in the current study contribute to supervisory power and trust theory by linking some combination of the five types of power to subordinate trust in supervisors in a collectivist culture. As Hofstede (1991) claimed, there are cultural differences in managerial leadership and it is important to understand the specific behaviours of people with different work values from different cultural contexts. It cannot be readily assumed that managers from other cultures would use power in ways similar to Western managers. In the Western organizational setting, for example, reward power seems to be directly connected with supervisory trust (Mayer, et al, 2011). In individualistic cultures such as the U.S.A. and U.K., rewards are given contingently on individual performance. A variety of rewards can be offered in the incentive system and two-way communication and counseling are widely used in the performance evaluation process. Although there has been a shift to more systemetic performance appraisal systems in Turkey, due to high power distance, social inequality and hierarchy, superiors generally have the absolute authority to evaluate subordinates. Standards of performance are rather vague and employees do not actively participate in the evaluation process (Aycan et. al., 2000). In many cases, relations and emotions get in the way of effective performance evaluations. Thus, it can be expected that superiors' use of reward power for individual performance may make many Turkish employees suspicious of superiors and may even decrease their trust level. We can conclude that the cultural qualities of Turkey account for the combined effect of reward power with personal or relationship power on supervisory trust. This discussion may draw attention to potential cross cultural management issues.

As a matter of fact, all forms of power bases imply a "power over" view of the world, suggesting that the power holder is somewhat superior to the other one. While "power with" approaches of leaders provide a supportive, trusting and healthy organizational culture, "power over" approaches are rather controlling, manipulative and stress-inducing. Thus, guidelines for the use of performance-contingent reward power, as well as performance-contingent coercive power by supervisors should be clearly explained by the organization. As to the proper use of legitimate power, managers should be cautioned to use their legitimate rights properly, follow policies and procedures consistently and rightfully as well as provide instructions and guidance clearly.

A major dilemma and the challenge of today's organizations is to enhance all the power bases of managers so as to achieve organizational goals and employee satisfaction. Organizations may provide managers with both formal and informal training that aim to develop leadership qualities associated with expert and referent power. Organizations should encourage continuous self-learning, coaching and mentoring, and provide their managers with specific job-related training. Enhancing their referent power base is not an easy goal to achieve, however. Human relations and emotional competence training may be provided, which should "focus on the competencies needed most for excellence in a given job or role" (Goleman, 1998, 251).

\section{Limitations and recommendations}

This study is not without limitations. Cross-sectional design of the study and self-reports taken from each respondent presents the problem of common method variance. The use of convenience sampling as data collecting procedure and small study sample might limit the generalizability of our results. Besides, the relationships found in this study are correlational and not causal. The 
Özarall1, N. (2015). The impact of social power bases on perceived trust: Do Turkish managers still follow the Akhi order?. International Journal of Social Sciences and Education Research, 1 (1), 64-87.

ways in which managers influence their employees depend on many variables, including the personality of the leader, the size, sector and the structure of the organization, the skills, education level and personalities of group members, the task or assignment at hand, etc. Such variables can be included in future research. Our study is conducted in a collectivist culture. The concepts of power and authority are rather multidimentional and how they are perceived differs from one culture to another. However, most of the findings in this study are consistent with previous research findings conducted in the western culture. This might bring us to make a claim that the pattern of power relationships may not be culture-bound. With future research, however, direct cross cultural comparisons can be made to come to a conclusion.

\section{References}

Afza, M. (2005). Supervisor-subordinate relationships and satisfaction in Indian small business enterprises. VIKALPA, 30 (3), 11-19.

Akça, G. (2004). Ahilik Geleneği ve Günümüz Fethiye Esnafi. Türkiyat Araştırmaları Dergisi,(14), 209219.

Altınkurt, Y. \& Yılmaz, K. (2012). Relationship between School Administrators' Organizational Power Sources and Teachers' Organizational Citizenship Behaviors. Educational Sciences: Theory \& Practice, 12(3), Summer, 1843-1852.

Aslanargun, E. (2009). İlköğretim ve lise müdürlerinin okul yönetiminde kullandı̆̆g gü̧ türleri, Yayımlanmamış Doktora Tezi, Ankara Üniversitesi Eğitim Bilimleri Enstitüsü, Ankara. (The power bases that primary school and high school principals use in school management, Unpublished Doctoral Dissertation, Ankara University Institute of Social Sciences), Ankara.

Aycan, Z. (2001). Human resource management in Turkey: Current issues and future challenges. International Journal of Manpower, 22, 3, 252-260.

Aycan, Z. \& Kanungo, R. N. (1998). Paternalism: Towards conceptual refinement and operationalization, Paper presented at the 14th International Congress of Cross-Cultural Psychology, Bellingham, August.

Aycan, Z., Kanungo, R. N., Mendonca, M., Yu, K., Deller, J., Stahl, G., \& Khursid, A. (2000). Impact of culture on human resource management practices: a ten-country comparison Applied Psychology: An International Review, 49,1, 192-220.

Aydın, M. (1994). Eğitim Yönetimi (Kavramlar, Kuramlar,Süreçler, İlişkiler). Education Management (Concepts, Theories, Processes, Relationships).4th ed. Genişletilmiş 4. Baskı.Ankara: PegemA, Yayın No:4.

Bağcı, Z. \& Bursalı, Y. M. (2011). Yöneticilerin güç kaynaklarının çalışanların örgüte bağlılıkları üzerine etkisi: Calışanların algılamalarına bağımlı analitik bir inceleme (Effects of managerial power bases on employees: An empirical study of employee dependent perceptions. Pamukkale Üniversitesi Sosyal Bilimler Enstitüsü Dergisi (Pamukkale University, Journal of Social Sciences Institute), Say1 9, 2011, 9-21.

Barron, R. M., \& Kenny, D. A. (1986). The moderator-mediator variable distinction in social psychology research: Conceptual, strategic, and statistical consideration. Journal of Personality and Social Psychology, 51(6), 1173-1182.

Bass, B. M., \& Aviolo, B. J. (1990). The implications of transactional and transformational leadership for individual, team, and organizational development. Research in Organizational Change and Development, 4, 231-272.

Blau P. (1964). Exchange and Power in Social Life. Wiley: New York. 
Özarallı, N. (2015). The impact of social power bases on perceived trust: Do Turkish managers still follow the Akhi order?. International Journal of Social Sciences and Education Research, 1 (1), 64-87.

Bozaykut, T. (2009). The effect of perceived supervisor power on trust in supervisor: An application in notfor-profit health care institutions. Master's thesis, Marmara University, Institute of Social Sciences.

Çagatay, N. (1989). Bir Turk kurumu olan Ahilik (The Akhism as a Turkish Institution), Türk Tarih Kurumu Yayınları, Ankara.

Carlson, R. J., Carlson, D. S., \& Wadsworth, L.L. (2000). The relationship between individual power moves and group agreement type: An examination and model. Advanced Management.

Chen, S. C. \& G. S. Dhillon (2003). Interpreting Dimensions of Consumer Trust in E-Commerce. Information Technology and Management, 4(2-3), 303-318.

Clarke, J. (2002). Skleton key-Communication and politics in workplace. MESS Publishing, Istanbul.

Dirks, K. T. \& Ferrin, D. L. (2002). Trust in leadership: Meta-analytic findings and implications for research and practice. Journal of Applied Psychology, 87(4), 611-628.

Doney P. M., Cannon J. P., \& Mullen, M. R. (1998). Understanding the influence of national culture on the development of trust. Academy of Management Review, 23(3), 601-620.

DuBrin, A. J. (2004). Leadership: Research Findings, Practice and Skills. HoughtonMifflin, NewYork.

Elangovan, A. R. \& Xie J.L. (2000). Effects of perceived power of supervisor on su.bordinate work attitudes. Leadership and Organization Development Journal, 21(6), 319-328.

Elias S. (2008). Fifty years of influence in the workplace. The evolution of the French and Raven power taxonomy. Journal of Management History, 14(3), 267-283.

Erçetin, Ş. Ş. (1993). Ast-Üst İlişkileri (Okul müdürü ve Öğretmenlerin Bbrbirlerini etkilemekte kullandıklarl güçler). Superior-subordinate relations (Power bases used by school principals and teachers to influence each other). Ankara:Şafak Matbaacılık Ltd.Şti.

Fikret-Pasa, S. (1999). Leadership influence in Turkey: the case of a high power distance and collectivist culture, Unpublished Manuscript.

Fikret-Pasa, S., Kabasakal, H., \& Bodur, M. (2001). Society, organizations, and leadership in Turkey. Applied Psychology: An International Review, Vol. 50,4, 559-589.

French. J., \& Raven, B. H. (1959). The bases of social power. In D. Cartwright (Ed.). Studies in social power: pp.150-167. Ann Arbor: University of Michigan. Institute for Social Research.

Frost, T.F. \& Moussavi, F. (1992), The relationship between leader power base and influence: the moderating role of trust. Journal of Applied Business Research, 8(4), 9-14.

Gibson, J. L, Ivancevich, J. M., Donnelly, J. H., \& Konopaske, R. (2012). Organizations: Behavior, structure, processes (14th ed.). New York, NY: McGraw-Hill Irwin.

Gaski, J. F. (1986). Interrelations among a channel entity's power sources: Impact of the exercise of reward and coercion on expert, referent, and legitimate power sources. Journal of Marketing Research, 18, 6277.

Gillespie, N., \& Mann, L. (2004). Transformational leadership and shared values: The building blocks of trust. Journal of Managerial Psychology,19, 588-607.

Goleman, D. (1998). Working with emotional intelligence. New York: Bantum Books.

Gupta, B. \& Sharma, N. K. (2008). Complience with bases of power and subordinates' perception of superiors: Moderating effect of quality of interaction. Singapore Management Review, 30 (1).

French \& Raven (1959). Bases of social power. Journal of Applied Psychology,74(4), 561-567. 
Özarall1, N. (2015). The impact of social power bases on perceived trust: Do Turkish managers still follow the Akhi order?. International Journal of Social Sciences and Education Research, 1 (1), 64-87.

Hardin, R. (2004). Distrust. Russell Sage Foundation series on trust, 8. New York: Russell Sage Foundation.

Hinkin, T.R. \& Schriesheim, C.A. (1989). Development and application of new scales to measure the French and Raven (1959) bases of social power. Journal of Applied Psychology, Vol. 74 No. 4, 561567.

Hofstede, G. (1980). Culture's consequences: International differences in work-related values. Sage: Newbury Park, CA.

Hofstede, G. (1991). Cultures and organizations: Software of the mind. London:McGraw-Hill.

House, R., Hanges, P. J., Javidan, M., Dorfman, P. W., \& Gupta, V. (2004). Culture, leadership and organizations: The GLOBE study of 62 cultures. Thousand Oaks, CA: Sage.

Ivancevich, J.M., Konopaske, R. \& Matteson, M.T. (2011). Organizational Behavior and Management (9th ed.). McGraw-Hill International Edition.

Jung, D. \& Avolio, B. (1999). "Effects of leadership style and followers' cultural orientation on performance in group and individual task conditions", Academy of Management Journal, Vol. 42, 208-18.

Jung, D. I., Bass, B. M. \& Sosik, J. J. (1995). 'Bridging leadership and culture: a theoretical consideration of transformational leadership and collectivistic cultures'. The Journal of Leadership Studies, 2(4), 318 .

Kabasakal, H. \& Bodur, M. (1998). Leadership, values and institutions: the case of Turkey. Paper presented at Western Academy of Management Conference, Istanbul, June.

Karagül, M. (2012). New economic approaches in the context of the "Akhism" with human and social capital. American International Journal of Contemporary Research, Vol. 2 No. 2; February.

Karatop, B., Karahan, A. G. \& Kubat, C. (2011). First application of total quality management in Ottoman Empire: Ahi organization. 7th Research/Expert Conference with International Participations "QUALITY 2011“, Neum, B\&H, June $01-04$.

Knapp, R. (1990). Power tactics. Education Canada, 15-19.

Koslowsky, M., Schwarzwald, J., \& Ashuri, S. (2001). On the relationship between subordinate's compliance to power sources and organizational attitudes. Applied Psychology, 50, 455-476.

Lee, K. L. \& Low, G. T. (2012). Supervisory power and satisfaction with supervision in Malaysian manufacturing companies: The moderating effect of work autonomy. African Journal of Business Management, 6 (22), 6530-6545.

Lunenburg F. C. (2012). Power and leadership: An influence process. International Journal of Management, Business and Administration, 15(1).

Liao, Li-Fen (2008). Knowledge-sharing in R\&D departments: a social power and social exchange theory perspective. The International Journal of Human Resource Management, 19(10), October 1881-1895.

Luthans, F. (2011). Organizational behavior (11th ed.). New York, NY: McGraw-Hill Irwin.

Mayer, R.C. \& Davis, J.H. (1999). The effect of the performance appraisal system on trust for management: A field quasi-experiment. Journal of Applied Psychology, 84, 123-136.

Mayer, R. C., Philip B., James H. D. \& Mark B. G. (2011). The effects of changing power and influence tactics on trust in the supervisor: A longitudinal field study. Journal of Trust Research, 1:2, 177-201.

McAllister, D.J. (1995). Affect- and cognition-based trust as foundations for interpersonal cooperation in organizations. Academy of Management Journal, 38, 24-59. 
Özarallı, N. (2015). The impact of social power bases on perceived trust: Do Turkish managers still follow the Akhi order?. International Journal of Social Sciences and Education Research, 1 (1), 64-87.

MacKenzie, S.B., Podsakoff, P.M. and Rich, G.A. (2001), “Transformational and transactional leadership and salesperson performance”. Journal of the Academy of Marketing Science, Vol. 29 No. 2, 115-34.

Morrow, J. L., M. H. Hansen \& A. W. Pearson (2004). The Cognitive and affective antecedents ofgeneral trust within cooperative organizations. Journal of Management Issues 16(1), 48-64.

Nadaee, T., Alavi, K. \& Ramezani, Z. N. (2012). Employees' effectiveness. World Applied Sciences Journal, 18 (10), 1400-1411.

Nelson, D. L., \& Quick, J. C. (2012). Understanding organizational behavior (4th ed.). Mason, OH: South-Western/Cengage Learning.

Perry, R. W. (2004). The relationship of affective organizational commitment with supervisory trust. Review of Public Personnel Administration, 24, 133-149.

Pierro, A., Raven, B. H., Amato C. \& Belanger, J. J. (2012). Bases of social power, leadership styles, and organizational commitment. International Journal of Psychology, 2012, 1-13.

Podsakoff, P. M., MacKenzie, S. B., Paine, J. B., \& Bachrach, D. G. (2000). Organizational citizenship behaviors: a critical review of the theoretical and empirical literature and suggestions for future research. Journal of Management, 26(3), 513-563.

Rahim, M. A. (1989). Relationships of leader power to compliance and satisfaction with supervision, evidence from a national sample of managers". Journal of Management, 15, 545-557.

Rahim, M. A., Antonioni, D., Krumov K. \& Illieva, S. (2000). Power, conflict, and effectiveness: A crosscultural study in the United States and Bulgaria. European Psychologist, 10, 28-33.

Rahim, M. A., Antonioni, D., \& Psenicka, C. (2001). A structural equations model of leader power, subordinates' style of handling conflict, and job performance. The International Journal of Conflict Management, Vol. 12(3), 191-211.

Raven, B. H. (1992). A power/interaction model of interpersonal influence: French and Raven thirty years later. Journal of Social Behavior and Personality, 7, 217-244.

Raven, B. H. (2008). The bases of power and the power/interaction model of interpersonal influence. Analyses of Social Issues and Public Policy, Vol. 8, No. 1, 1-22.

Raven, B. H., Schwarzwald, J. \& Koslowsky, M. (1998). Conceptualizing and measuring a power/interaction model of interpersonal influence. Journal of Applied Social Psychology, 28, 4, 307-332.

Robbins, S P. (2003). Organisational Behaviour, Prentice Hall, New Jersey.

Rousseau, D. M., Sitkin, S. B., Burt, R. S., \& Camerer, C. (1998) . Not so different after all: A crossdiscipline view of trust. The Academy of Management Review, 23, 393-404.

Sargut, S. (2001). Kültürlerarası farklılaşma ve yönetim, Verso Yayıncılık, Ankara. (Intercultural Differentiation and Management, Varso Publishing, Ankara).

Sarıtaş, M. (1991). “İlkokul Müdürlerinin Etki Sürecine İlişkinYeterlikleri”.Yayınlanmamış Doktora Tezi (Competencies of primary school principals as to the influence process) Unpublished Doctoral Dissertation, Ankara: Hacettepe University.

Shockley-Zalabak P., Ellis, K., \& Winograd G. (2000). Organizational trust: what it means, why it matters. Organizational Development Journal, 18(4), 35-48.

Spencer-Oatey, H. (1997). Unequal relationships in high and low power distance societies: a comperative study of tutor-student role relationshis in Britain and China. Journal of Cross-Cultural Psychology, 28, 284-302. 
Özarall1, N. (2015). The impact of social power bases on perceived trust: Do Turkish managers still follow the Akhi order?. International Journal of Social Sciences and Education Research, 1 (1), 64-87.

Steensma, H. \& van Milligen, F. (2003). Bases of power, procedural justice, and outcomes of mergers: The push-and-pull factors of influence tactics. Journal of Collective Negotiations in the Public Sector, 30(2), 113-134.

Steensma, H. \& Visser, E. (2007). Procedural justice and supervisors' personal power bases: Effects on employees perceptions of performance appraisal sessions, commitment, and motivation. Journal of Collective Negotiations, 31(2), 101-118.

Van Dyne, L., Vandewalle, D., Kostova, T., Latham, M. E., \& Cummings, L. L. (2000). Collectivism, propensity to trust and self-esteem as predictors of organizational citizenship in a nonwork setting. Journal of Organizational Behavior, 21, 3-23.

Wasti, S. A., Tan, H. H., Brower, H. H. \& Önder, Ç. (2007). Cross-cultural measurement of supervisor trustworthiness: An assessment of measurement invariance across three cultures. The Leadership Quarterly, 18, 477-489.

Yılmaz, K. \& Altınkurt, Y. (2012). Okul yöneticilerinin kullandıkları güç kaynakları ile öğretmenlerin iş doyumu arasındaki ilişki", Kastamonu Eğitim Dergisi, Mayıs, Cilt:20 No:2, 385-402. ("The relationship between the power bases used by school principals and teachers' job satisfaction"), Kastamonu Journal of Education, May, 20(2), 385-402.

Yukl, G. A. (1981). Leadership in Organizations, Englewood Cliffs, N.J.: Prentice-Hall.

Yukl, G. A., \& Falbe, C. M. (1991). Importance of different power sources in downward and lateral relations. Journal of Applied Psychology, 76, 416-423. 